\title{
Small-scaled lateral variations of an organic-rich formation in a ramp-type depositional environment (the Late Jurassic of the Boulonnais, France): impact of the clastic supply
}

\author{
Ebraheem Hatem $^{1}$, Nicolas Tribovillard ${ }^{1}{ }_{*}$, Olivier Averbuch ${ }^{1}$, Viviane Bout-Roumazeilles ${ }^{1}$, \\ Alain Trentesaux ${ }^{1}$, Jean-François Deconinck ${ }^{2}$, François Baudin ${ }^{3}$ and Thierry Adatte ${ }^{4}$ \\ ${ }^{1}$ Univ. Lille, UMR LOG 8187 université Lille 1 - ULCO - CNRS, laboratoire d'océanologie \& géosciences, 59000 Lille, France \\ ${ }^{2}$ Université de Bourgogne/Franche Comté, UMR CNRS biogéosciences 6282, 6 boulevard Gabriel, 21000 Dijon, France \\ 3 Sorbonne universités, université Pierre et Marie Curie, UMR CNRS 7193 ISTeP, Case courrier 117, 4 place Jussieu, \\ 75252 Paris Cedex 05, France \\ ${ }^{4}$ Université de Lausanne, institut des sciences de la terre, bâtiment Géopolis 3879, 1015 Lausanne, Switzerland
}

\begin{abstract}
We studied a potential petroleum source rock deposited in a clastic-dominated ramp environment: the Argiles de Châtillon Formation (Kimmeridgian-Tithonian, Boulonnais area, northern France). The formation was deposited along a proximal-distal gradient on this ramp affected by synsedimentary fault movements. A sedimentological, mineralogical and geochemical study was conducted to decipher the distribution patterns of sedimentary parameters along such a depth increase over the ramp. It comes out that smectite distribution unexpectedly mimics the lateral depth evolution despite the good floatability of the mineral. It is also observed that the Argiles de Châtillon could accumulate noticeable amounts of organic matter in spite of paleoenvironmental conditions that were not specifically prone to organic matter preservation and burial (sedimentation rate, mineral particle grain size, productivity, oxygenation level...). Conversely, reactive iron, when being present in limited abundance, must have allowed sulfide ions to react with organic molecules instead of forming iron sulfides, which fostered organic matter preservation and accumulation. This protecting role of organic sulfide incorporation (additional to other favorable factors) cannot exist if reactive iron is relatively abundant. Lastly, our results (still fragmentary) suggest that smectite minerals could carry reactive iron, which would have occasionally hampered organic-matter preservation.
\end{abstract}

Keywords: Kimmeridgian-Tithonian / Boulonnais / organic matter / petroleum source rocks / geochemistry / clay minerals

\begin{abstract}
Résumé - Importance des variations latérales discrètes dans les apports détritiques, observées dans des faciès de rampe sédimentaire riches en matière organique (Jurassique supérieur du Boulonnais). La formation des Argiles de Châtillon (Kimméridgien-Tithonien, Boulonnais) est un bon analogue géologique de roche mère pétrolière déposée en contexte de rampe clastique. Ces dépôts se sont mis en place le long d'un transect proximal-distal sur une rampe affectée par des mouvements tectoniques synsédimentaires. Pour mettre en évidence et comprendre la distribution des paramètres sédimentaires en fonction de l'évolution de la profondeur, une étude sédimentologique, minéralogique et géochimique fut entreprise. Il en ressort que la distribution de la smectite au sein du cortège argileux respecte ce gradient, malgré la flottabilité reconnue de ce minéral. Il apparaît également que les Argiles de Châtillon ont pu accumuler des quantités sensibles de matière organique malgré un contexte de dépôt peu favorable à la préservation et à l'enfouissement de celle-ci. En revanche, le fer réactif, quand il était présent en faible quantité dans les sédiments, a pu permettre aux ions sulfures de réagir avec les molécules organiques, plutôt que de former des sulfures de fer. Cette sulfuration a pu accroître la résistance de la matière organique à la dégradation microbienne, ce qui explique la bonne préservation du carbone organique. Ce rôle protecteur de la vulcanisation naturelle (qui s'ajoute à d'autres facteurs favorables) ne peut pas s'exercer si le fer réactif est relativement abondant. Nos résultats (encore fragmentaires) suggèrent également que la smectite
\end{abstract}

\footnotetext{
*Corresponding author: nicolas.tribovillard@univ-lille1.fr
} 
(qui est un minéral pouvant véhiculer du fer faiblement lié au réseau cristallin) pourrait, dans certains cas, limiter la préservation de la matière organique.

Mots clés : Kimméridgien-Tithonien / Boulonnais / matière organique / roches mères d'hydrocarbure / géochimie / minéraux argileux

\section{Introduction}

The Late Jurassic marlstones of the Argiles de Châtillon Formation (Fm.) are well exposed along the coastal cliffs of the Boulonnais area (northernmost France), between the Cap Gris$\mathrm{Nez}$ (or Gris-Nez Cape) and Equihen (south of Boulogne-surMer; Fig. 1). These shelf sediments are lateral time equivalents of the distal organic-rich sediments of the Kimmeridge Clay Fm. deposited in the Wessex Basin (Dorset, UK). The Argiles de Châtillon Formation, though deposited in a clastic-dominated, relatively shallow (sometimes above the storm wave base) ramp environment, is relatively rich in marine organic matter (OM) and is a potential petroleum source rock. Along this ramp, the Argiles de Châtillon deposits recorded a proximal-distal gradient, with the shallowest conditions close to the Cap Gris-Nez, and the more distal conditions close to the cities of Wimereux and Boulogne-sur-mer (Cap de la Crèche section, Fig. 1; Mansy et al., 2007). The Boulonnais area has been experiencing an extensional tectonics regime during the Late Jurassic, expressed through synsedimentary faulting (Hatem et al., 2014, 2016; Mansy et al., 2007). The aim of the paper is to examine the lateral evolution of the depositional conditions of this potential source rock, in order to derive some general forcelines for a better understanding of $\mathrm{OM}$ accumulation on continental platforms exposed to relative sea-level variations and synsedimentary tectonics. More specifically, emphasis will be set on the roles of iron and the composition of clay-mineral assemblages in the processes of OM preservation. The present paper is partly grounding upon a synthesis of many papers published during two decades, dealing with the Late Jurassic deposits of the Boulonnais (see below); it also presents new results on the clastic fraction of the Argiles de Châtillon Fm. This work tries to draw some guidelines about $\mathrm{OM}$ accumulation that can be transposed from the formation at stake here to other similar platform settings of any age or location.

\section{Geological framework and previous results}

The Kimmeridgian-Tithonian series exposed along the Boulonnais cliffs are part of the northern margin of the WealdBoulonnais basin (sometimes called also Weald-Boulonnais anticline due to its present structure). This margin, alike the adjacent North Sea and Wessex basin, was affected by a major Late Jurassic- Early Cretaceous rifting event (Minguely et al., 2010 and reference therein) coeval with the general propagation of the Atlantic rift zone, north of the Gibraltar-Newfoundland fracture zone. The related pattern of subsidence and uplift induced the preservation of shallow marine Upper Jurassic and continental Lower Cretaceous (Wealdian) deposits in a restricted fault-bounded Boulonnais embayment upon which the presentday exposure is molded (Fig. 1). Extensive studies of the Boulonnais sections have provided a depositional and sequence stratigraphical framework that may be used to help interpret variations in $\mathrm{OM}$ content and composition, in response to fluctuating relative sea-level (e.g., Al-Ramadan et al., 2005; El Albani et al., 1993; Bialkowski et al., 2000; Braaksma et al., 2006; Deconinck et al., 1996; Herbin et al., 1995; Proust et al., 1995; Schlirf, 2003; Tribovillard et al., 2001; Wignall and Newton, 2001; Williams et al., 2001). The most-studied section is exposed at the Cap de la Crèche, between Wimereux and Boulogne-sur-mer (Fig. 1). There, the $29 \mathrm{~m}$-thick Argiles de Châtillon Fm. (autissiodorensis and elegans ammonite zones) is well visible, being bracketed between the upper part of the Grès de Châtillon Fm. below (shoreface sandstone formation, eudoxus zone), and the base of the Grès de la Crèche Fm. above (another shoreface sandstone formation, scitulus zone; Deconinck et al., 1996; Geyssant et al., 1993; Herbin et al., 1995; Wignall et al., 1996). The siltstones and shales of the Argiles de Châtillon Fm. represent a low-energy shelf facies deposited below wave base, but revealing some storm influence with some shelly limestone beds (Fürsich and Oschmann, 1986) and thin sandstone bodies showing hummocky cross stratifications. Like the more distal time equivalent shales and mudstones exposed at Kimmeridge on the Dorset coast (Cox and Gallois, 1981; Waterhouse, 1999) or Yorkshire (Ramanampisoa et al., 1992), these sediments are also organic-rich in part (Deconinck et al., 1996; Dunn, 1972; Geyssant et al., 1993; Herbin and Geyssant, 1993; Herbin et al., 1991; 1995; Proust, 1994; Proust et al., 1993), but their OM has a more mixed origin (El Albani et al., 1993; Herbin and Geyssant, 1993; Herbin et al., 1995). The higher pyrite contents, and the depauperate in situ macro and microbenthos and reduced bioturbation have long been used to suggest reducing and "stagnant", but not persistently anoxic, conditions (Ager and Wallace, 1966, 1970; Barnard and Shipp, 1981). Several orders of cyclicity are recorded within the Argiles de Châtillon; the most prominent are:

- the Milankovitch-type (climatic) primary cycles (ca. $20 \mathrm{ky}$, Herbin et al., 1995);

- the superimposed longer-term cycles observed here ( $c a$. 500 ky; Herbin et al., 1995; Waterhouse, 1999).

Sequence stratigraphical studies of the Wimereux section (Al-Ramadan et al., 2005; Braaksma et al., 2006; Herbin et al., 1995; Proust, 1994, Proust et al., 1993, 1995) allow us to relate observed variations in organic facies to changes in relative sealevel. Herbin et al. (1995) pointed out that relative sea-level rise was not the single cause for OM accumulation. Instead, these authors suggest that three parameters must act in conjunction:

- physiography (concerning the shape of the basin and the volume of sediments available);

- transgression (influencing the size of the area producing the organic material and the water depth);

- climate (governing the quality of the OM and the variation of primary productivity). Note that the climate of this period is reputed to have been warm (Brigaud et al., 2008; Dera et al., 2011).

As detailed descriptions of the lithofacies and stratigraphy of the "reference" section of the Cap de la Crèche have been 

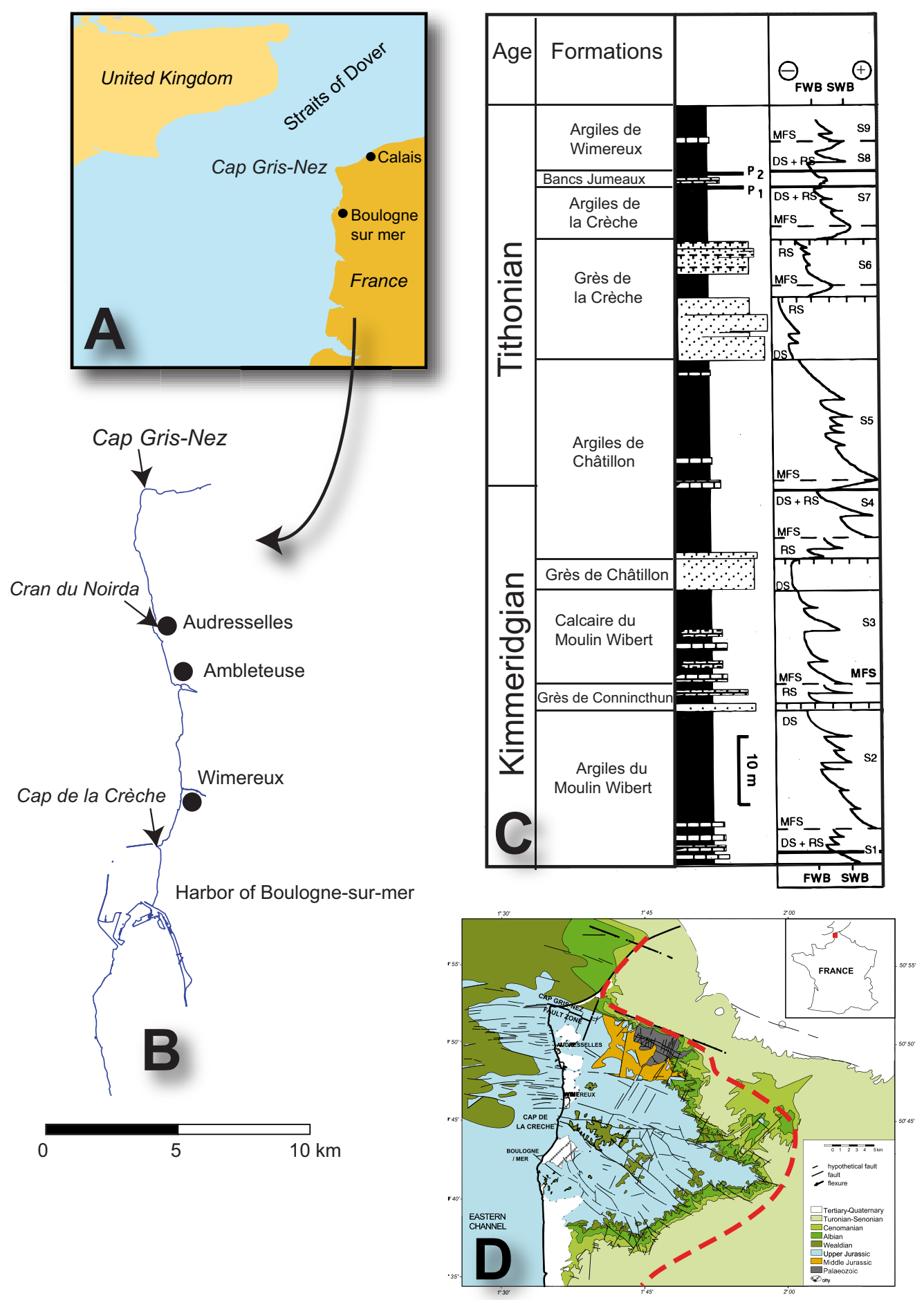

Fig. 1. A and B: maps showing the location of the study area, between the Gris Nez Cape and the city of Wimereux. C: simplified lithostratigraphic log of the Late Jurassic formations cropping alongshore the Boulonnais (after Deconinck et al., 1996). FWB and SWB stand for fair-weather wave base and storm-weather wave base, respectively. P1 and P2 stand for the two horizons rich in phosphatized shells. D: geological setting of the Boulonnais area (after Mansy et al., 2007; Hatem et al., 2016).

given previously in Proust (1994), Proust et al. (1995), Herbin et al. (1995), Deconinck et al. (1996) and Wignall and Newton (2001), only a summary needs be offered here. The Grès de Châtillon consists of brown- to orange-colored sandstones and sandy marlstones with common cross-bedding and wave ripples, and intense bioturbation (especially U-shaped and rhizocorallium, ophiomorpha and thallasinoides burrows). The formation ends with bioturbated limestone beds that mark the transition to the overlying Argiles de Châtillon Fm. that consists of claystone and siltstone accumulations with some intervals of laminated paper shales (Fig. 2), and a laterally variable number of local intercalated limestone beds, some of which are 


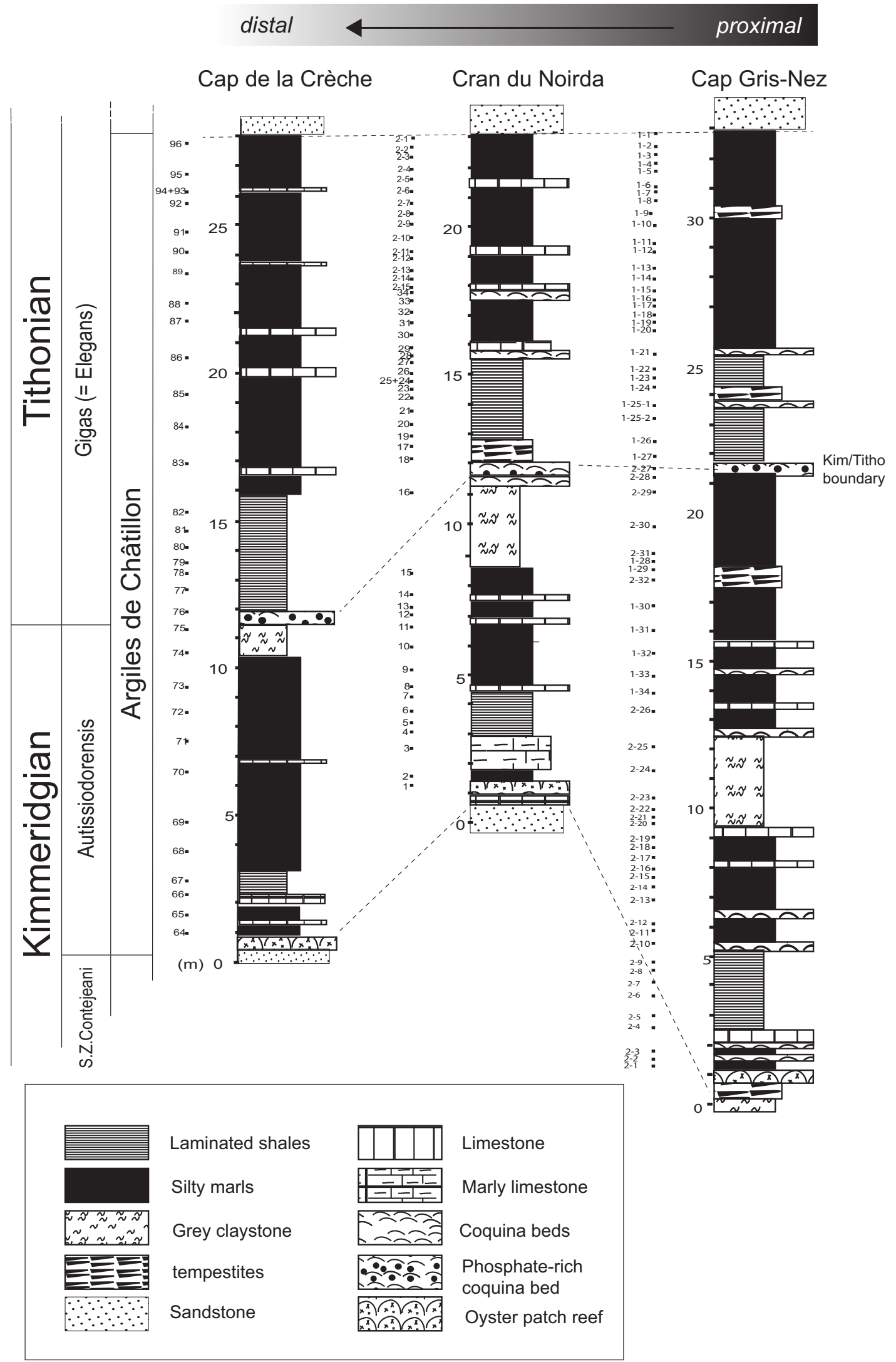

Fig. 2. Simplified logs of the studied three sections. Numbers refer to the samples. 
diagenetic in origin (Hatem et al., 2016). The marlstones show a gradual enrichment in silt in the upper part of the formation. The Cran du Noirda section is characterized by the common occurrence of storm beds, notably around the KimmeridgianTithonian boundary (autissiodorensis-elegans zone).

The organic content of the Argiles de Châtillon Fm. (observed from the Cap de la Crèche section) is dominated by amorphous organic matter (AOM; Tyson, 1995). AOM represents the part of the kerogens the origin and nature of which cannot be determined through palynofacies observation alone (Tyson, 1995). Here, AOM is itself dominated by two main varieties distinguished on the basis of their color: orange or brown (see description and microphotographs in Tribovillard et al., 2001). Orange AOM exhibits distinct (and in some cases, almost angular) edges, and has a gel-like texture. Brown AOM has a more heterogeneous "flock" texture, less distinct "fuzzy" outlines, and tends to be less lustrous; in untreated kerogen slides it exhibits a more granular texture and the presence of pyrite crystallites and tiny framboids. It is also associated with lower fluorescence intensities (Bialkowski et al., 2000; Tribovillard et al., 2001). In previous studies of the Kimmeridge Clay, orange AOM has been found to be nanoscopically amorphous, while brown AOM shows an ultralaminar ultrastructure which is thought to represent selectively preserved cell walls of microplankton (Boussafir et al., 1994, 1995a, b; Gelin et al., 1995, 1999). The ratio of the two types of AOM changes with the total organic carbon content (TOC) of the sediments, the proportion of orange AOM increases rapidly as TOC increases from 2 to $7 \%$ (Bialkowski et al., 2000; Boussafir and Lallier-Vergès, 1997; Tribovillard et al., 2001). The orange AOM is interpreted as resulting from natural vulcanization, a.k.a. sulfurization (reaction with sulfides and polysulfides, see below), whereas brown AOM is interpreted to result from selective preservation of resistant biopolymers (selective oxidation of metabolizable constituents; Boussafir et al., 1994, 1995a, b; Derenne et al., 1991; Largeau et al., 1990; Mongenot et al., 1997). Natural sulfurization is an early diagenetic process leading to the inter-or intramolecular incorporation of reduced inorganic sulfur species into low-molecular-weight functionalized lipids resulting in the formation of resistant high molecular weight abiotic "geopolymers" (Tegelaar et al., 1989). Recent works suggest that the intramolecular pathway dominates over the intermolecular pathway (Quijada et al., 2016 and references therein).

\section{Material and methods}

To study a transect through the area of the Boulonnais where Jurassic formations crop out, namely from Cap GrisNez to Equihen, we examined three sections of the Argiles de Châtillon Fm. located, respectively, at Cap Gris-Nez (proximal setting; 68 samples), Cran du Noirda (intermediate setting, north end of Audresselles Village; 51 samples) and Cap de la Crèche (distal setting; 33 samples). The proximal-distal gradient is thus observed over a distance of about $15 \mathrm{~km}$ and is not sharp: the facies variations from one section to one another are not strong. Figure 2 illustrates the lithologies observed in the three sections and sampling steps. The same basic facies successions can be observed in the three sections. The main differences consist of some variations in thickness and a laterally variable number of storm-induced coquina beds (Fig. 2). These tempestites are dominantly made of small oysters (Nanogyra nana) and thin levels of sandstones showing hummocky cross stratifications (HCS). The oyster shell beds are dominant in the proximal setting of Cap GrisNez whereas the HCS levels are more abundant in the more distal settings of Cran du Noirda (they are not observed in the Cap de la Crèche section, the most distal part of the studied transect). In these sections, we could identify the level that is considered to correspond to the Kimmeridgian-Tithonian boundary (Geyssant et al., 1993). This level is rich in phosphatic debris and shells, and lies on top of a thick, shellrich carbonate bed in the Cran du Noirda section (Proust et al., 1995). Notably, two laminated shale horizons are observed in each section; they are interpreted as deposited during marked elevation of sea-level and begin with a maximum flooding surface. Both laminated shale horizons have a high organic carbon content (up to $9 \%$ ) and, in the Cap de la Crèche section, are rich in orange-color AOM (Tribovillard et al., 2001).

For the three sections, grain-size distribution of the decarbonated fraction ( $\mathrm{HCl}$ digestion) was analyzed using a laser-equipped Malvern Mastersizer apparatus, following the protocole of Trentesaux et al. (2001). The decarbonated fraction is considered to be representative of the clastic, landderived component of the sediment, to which the authigenic fractions may be added (mainly pyrite framboids or crystals), as well as organic flocs. Tempestite beds were not taken into consideration for grain-size study. The limit between silt and clay (from a grain size point of view) is $4 \mu \mathrm{m}$ in the present paper. For all samples, the carbonate content was measured using a Bernard calcimeter (acid digestion followed by $\mathrm{CO}_{2}$ volume determination; accuracy $<5 \%$ ). The Rock Eval pyrolysis parameters were determined with a Rock Eval VI apparatus: total organic carbon content (TOC, in wt.\%), Tmax $\left({ }^{\circ} \mathrm{C}\right)$, and Hydrogen Index (HI, in mg hydrocarbon per g TOC; see all details about Rock Eval pyrolysis and parameters in Behar et al., 2001; Espitalié et al., 1985; Lafargue et al., 1998).

The determination of the major- and trace-element contents was carried out by ICP-OES and ICP-MS by the spectrochemical laboratory of the Centre de Recherches en Pétrographie et Géochimie of Vandœuvre-les-Nancy (geochemistry laboratory of the French Centre National de la Recherche Scientifique). The samples were prepared by fusion with $\mathrm{LiBO}_{2}$ and $\mathrm{HNO}_{3}$ dissolution. Precision and accuracy were both better than $1 \%$ (mean $0.5 \%$ ) for major-minor elements and $5 \%$ for trace metals, as checked by international standards and analysis of replicate samples (Carignan et al., 2001). Enrichment factors (EF) were calculated as: $\mathrm{X}_{\mathrm{EF}}=\left[(\mathrm{X} / \mathrm{Al})_{\text {sample }} /(\mathrm{X} / \mathrm{Al})_{\mathrm{AUC}}\right]$, where $\mathrm{X}$ and $\mathrm{Al}$ represent the weight $\%$ concentrations of element $\mathrm{X}$ and $\mathrm{Al}$, respectively. Samples were normalized using the average upper crust (AUC) compositions of McLennan (2001). Aluminum normalization is commonly used to minimize the effects of variable dilution by carbonate or biogenic silica, although certain caveats apply to this approach (for a discussion, see Van der Weijden et al., 2002). The convenience of using enrichment factors is that any value larger than 1.0 points to enrichment of an element relative to its average crustal abundance. In practical terms, EFs $>3$ represent a detectable enrichment of an element over average crustal concentrations, and EFs $>10$ represent a moderate to strong degree of enrichment (Algeo and Tribovillard, 2009). 


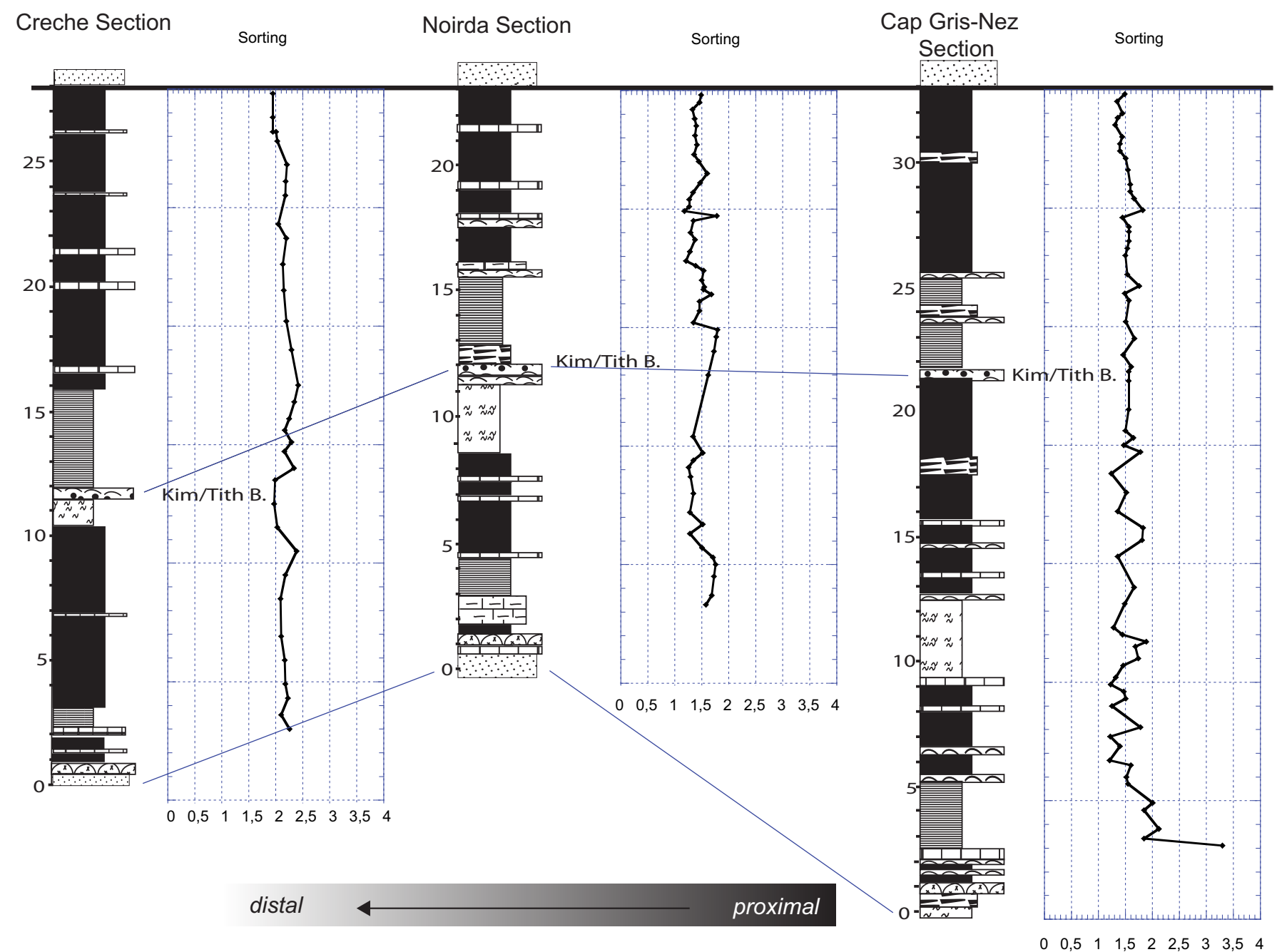

Fig. 3. Compared stratigraphic evolution of the sorting index for the studied three sections.

The $<2 \mu \mathrm{m}$ clay fraction was isolated and analyzed using the standard protocol for clay-mineral assemblage determination (a Bruker D4 Endeavour apparatus was used together with the Macdiff software; see detailed protocol in Bout-Roumazeilles et al., 1999).

Lastly, low-field magnetic susceptibility was measured on the dried samples, using a Kappabridge KLY 2 apparatus (three measures per sample) operating at an alternating magnetic field of $300 \mathrm{~A} / \mathrm{m}$ (frequency $920 \mathrm{~Hz}$ ). Low-field MS values were normalized with respect to sample mass to allow comparisons between samples of different density.

\section{Results}

The analytical results are gathered in Tables S1-S3 (see on-line supplementary data).

\subsection{Grainsize analysis}

The dominant size fraction is that of silt for the three sections. Consistently with the existence of the proximal-distal gradient, the most remote site of Cap de la Crèche yields a relatively important clay-size fraction (up to $20 \%$ ), while the most proximal Cap Gris-Nez site shows a relatively important fine-sand fraction (up to 20\%). In addition, sorting is smoother at Cap de la Crèche than at Cap Gris-Nez . The sorting index used here is the classic one defined by Folk and Ward (1957), using the $\Phi$ notation: $\left(\Phi_{84}-\Phi_{16}\right) \div 4+\left(\Phi_{95}-\Phi_{5}\right) \div 6.6$. Figure 3 and Tables S1 to S3 (supplementary data) summarize the lateral evolution of grain-size distribution.

\subsection{Clay-mineral assemblages}

The assemblages contain illite, smectite, kaolinite and chlorite in variable proportions. Chlorite is the less abundant clay mineral, and shows smoothed stratigraphic distributions. Smectite distribution is largely opposed to that of illite + kaolinite, which is also the case at the scale of the entire Late Jurassic in the Boulonnais (Deconinck et al., 1996). At the Cran du Noirda and Cap Gris-Nez sites, the smectite content starts increasing from the Kimmeridgian-Tithonian boundary upward, whereas the increase is observed only in the top three meters at Cap de la Crèche (Fig. 4).

\subsection{Rock Eval parameters}

Organic matter is present in the three sections, with TOC values falling into the $0.1-7.7 \%$ range (a maximum of $9 \%$ was recorded in the Cap de la Crèche section, as reminded above). 


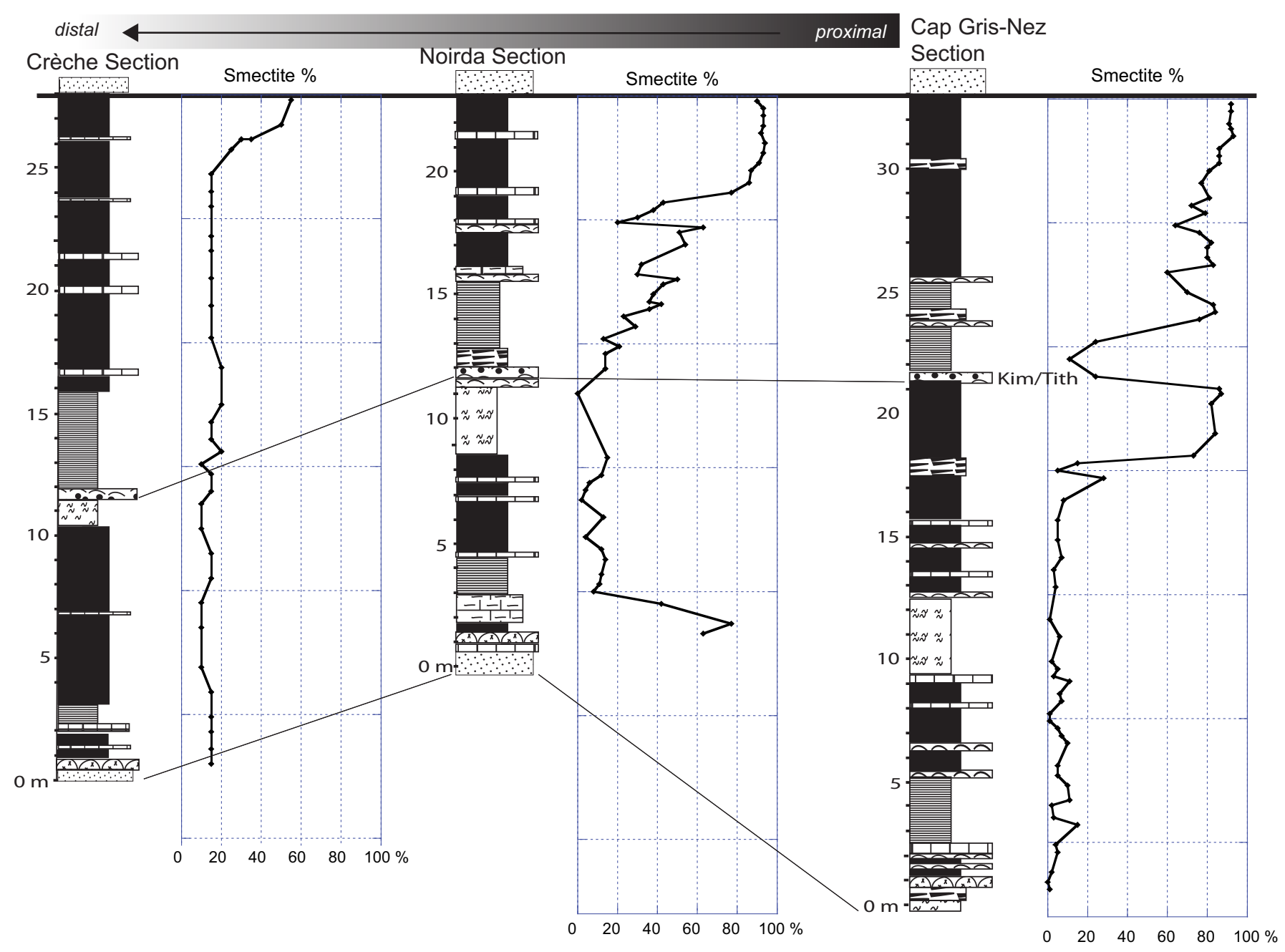

Fig. 4. Compared stratigraphic evolution of the proportion of smectite within the clay-sized assemblages for the studied three sections.

Figure 5 illustrates the distribution of the Tmax and HI values, as well as the TOC range and mean, for the three sections. All the samples (but 3) fall in the "immature" zone of the diagram, as determined by Tmax. The HI parameter shows that the samples of the three formations straddle the kerogen Types II and III, which indicates that a mixture of marine and terrestrial $\mathrm{OM}$ in variable proportions is present, for the three sites. The Cap de la Crèche samples are scattered between the lowest and highest ends of the sample sets. The Gris-Nez samples do not reach $\mathrm{HI}$ values as high as those of the other two sections. For the three sections, the highest TOC values are observed in the laminated shale levels. Lastly, a positive correlation is observed between TOC and HI, as already observed and discussed in Tribovillard et al. (2001).

\subsection{Magnetic susceptibility and carbonate content}

The stratigraphic distribution of magnetic susceptibility is, by and large, the same for the three sites, with a slight decrease upward in the section. Lastly, the vertical distribution of the carbonate content does not yield specific trends. At the Cap Gris-Nez, the high number of coquina beds induces more "noise" in the stratigraphic distribution.

\subsection{Trace metals}

A sample subset was analyzed for the elemental composition, 8 samples from the Cap Gris-Nez section, 19 samples from the Cran du Noirda section and 14 samples from the Cap de la Crèche section. The samples were taken below, within and above, respectively, the laminated shale levels, in order to cover a relatively wide array of TOC values. Focusing on the oxygen conditions of the depositional environment, the usual redox proxies, namely, uranium, vanadium and molybdenum (e.g., Algeo and Rowe, 2012; Brumsack, 2006; Scott and Lyons, 2012; Tribovillard et al., 2006) were observed. These elements show no or modest enrichments. Vanadium shows a clear linear correlation to the aluminum content, which indicates a terrigenous origin. In contrast, Mo and U show poor correlation with Al. Considering enrichment factors (EF), Mo and U show EFs close to the value 1 for the Cap de la Crèche samples, which means that the elements are present in proportions identical to what is observed for the average upper crust of the Earth. In other words, no authigenic enrichment is visible for this distal section. The samples of the more proximal sections (Cap Gris$\mathrm{Nez}$ and Cran du Noirda) show modest enrichments EF 


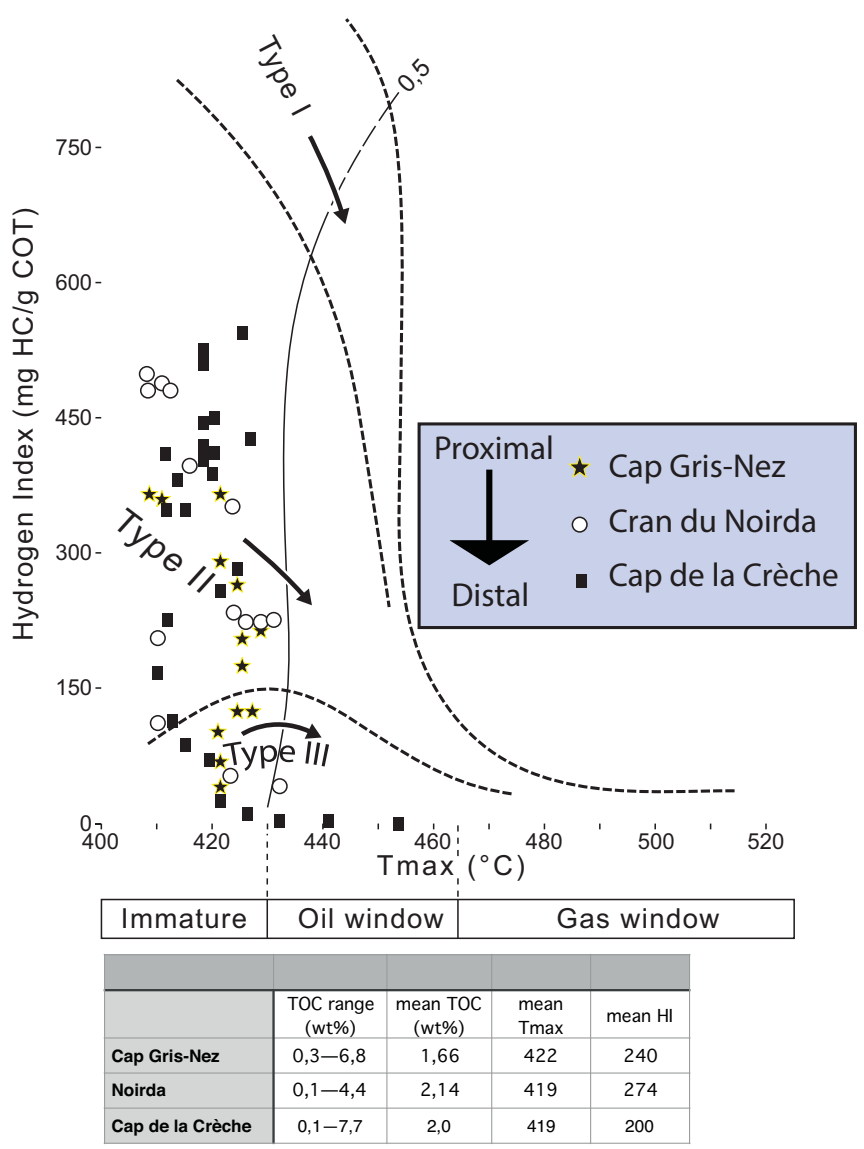

Fig. 5. Rock Eval data.

ranging from 1 to 6 for $\mathrm{U}$ and from 1 to 8 for Mo. A crossplot opposing the values of the enrichment factors of $U$ and Mo, respectively, is drawn (Fig. 6) to decipher the oxygenation conditions of the depositional environments (see explanations of such diagrams in Algeo and Tribovillard, 2009; Tribovillard et al., 2012). All samples (mixing the three sections) fall in the "oxic to suboxic" area of the diagram, largely close to the "oxic" zone with both U and Mo keeping with enrichmentfactor values below 10 .

Regarding proxies for paleoproductivity (Böning et al., 2015; Tribovillard et al., 2006), nickel and copper show enrichment factors below or close to the value 1, that is, no authigenic enrichment.

\section{Discussion}

\subsection{Smectite abundance and relative sea-level variations}

The distribution of clay minerals along the proximal-distal transect at stake here shows that smectite is more abundant in the proximal environments than in the distal one (Fig. 4). This observation is counter-intuitive, in that differential settling of clays usually induces smectite prevalence in remote settings, in relation to its high floatability (Chamley, 1989). However, this unexpected observation was already expressed at least for the deposits ranging from the Oxfordian/Kimmeridgian Boundary

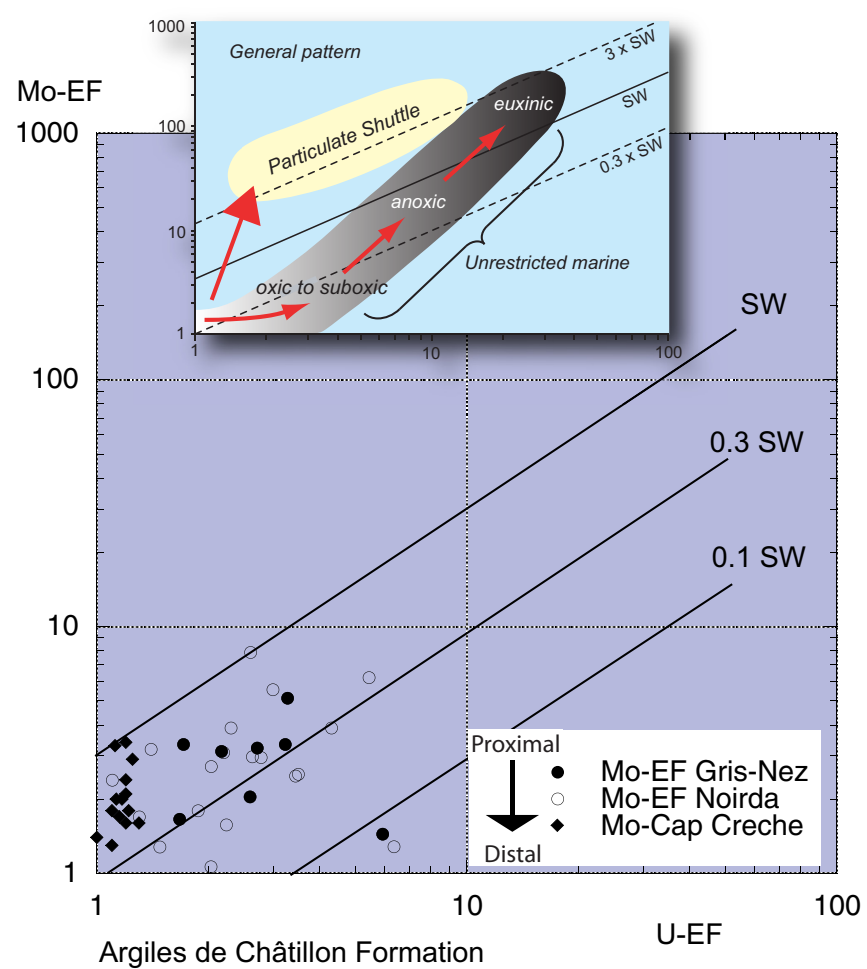

Fig. 6. Cross-plot opposing the respective enrichment factors of $U$ and Mo for the three sections studied, as designed by Algeo and Tribovillard (2009) to derive paleoenvironmental information.

to the end of the Tithonian of the Boulonnais (Deconinck et al., 1982; Hesselbo et al., 2009; Schnyder et al., 2000). These authors, grounding on their own results and those of published works, concluded that the landmass of the London-Brabant Massif was the likely source of detrital particles in the nearshore of the Boulonnais and that the low relief of this landmass would have been favorable to the steady-state erosion of smectite-rich soils. Hesselbo et al. (2009) observed the unusual occurrence of smectite in the shallowest environments throughout the Jurassic successions of the Boulonnais, whereas smectite is usually deposited in quiet offshore settings. Their interpretation is that during sea-level lowstand, the London-Brabant Massif was emerged and provided detrital smectite. Contrastingly, during sea-level highstand the massif was submerged and clay sedimentation was dominated by illite, kaolinite and I-S mixed-layer clays originating from more distant areas, including the Central, Armorican and Cornubian massifs.

The same view may apply at the scale of the Argiles de Châtillon Fm. The formation recorded an initial sea-level rise followed by a gradual sea-level fall (Deconinck et al., 1996; Proust, 1994; Proust et al., 1993, 1995). The sea-level fall was accompanied by the release of smectite from the emerged part of the London-Brabant Massif. The supply of smectite was recorded first by the proximal settings (Cap Gris-Nez) and gradually by the more distal settings (Cran du Noirda section and, in the end, Cap de la Crèche section; Fig. 4). What is noticeable here is that such a gradient in smectite distribution is observed on a scale of about $15 \mathrm{~km}$. With such distances, one 
would intuitively expect the dispersal of smectite particle inputs to be immediate, from a geological standpoint. As we have no hint that the Kimmeridgian-Tithonian boundary could be wrongly identified, basing on previous works and our own observations, we must conclude that smectite dispersal was gradual. We may suggest that local currents in the Boulonnais embayment could have limited smectite dispersal but this is only conjectural. However, in another geological setting (New Jersey margin), Deconinck and Vanderaveroet (1996) also observed a steep gradient of smectite proportions over a distance of $<50 \mathrm{~km}$, which cannot be ascribed to a change in particle sources or the climate. See also how smectite differential settling and climate influence may be discussed for Cenomanian deposits of France or Morocco (AgadirTarfaya area; Chamley et al., 1990; Deconinck and Chamley, 1995; El Albani et al., 1999; Gertsch et al., 2010). In the case of the Boulonnais, the smectite gradient cannot be accounted for by climatic variations and only sea-level variation coupled to differential settling is put forward (possibly in conjunction with local factors such as currents, seabed topography or mixing of water masses with contrasting salinity that can be evoked in an embayment).

Such a smectite gradient over relatively short distances (here, ca. $15 \mathrm{~km}$ ) is an interesting indication for all those using the composition of clay-mineral assemblages as a paleoclimatic or paleo-environmental tool. Variations in the abundance of smectite in an ancient sedimentary succession must be questioned in terms of sea-level variations, as well as in terms of evolution of on-land clay sources, even in smalldimension basins.

\section{2 potential oil source-rock despite lowly favorable conditions}

The second point to comment is that the Argiles de Châtillon Fm. has some of the characteristics of a potential petroleum source rock, as well as its lateral, time-equivalent counterpart of the Kimmeridge Clay Fm. in UK (Herbin et al., 1995; Tribovillard et al., 2005). However, the Argiles de Châtillon Fm. was deposited above the storm wave base, where sediment accumulation was overwhelmed by silt-sized particles, and not clay-sized ones. The Cap de la Crèche section was probably close or sometimes below the shoreface/ lower offshore limit. The most-OM-rich levels, namely, the laminated shales, are - unexpectedly - not enriched in claysized fraction relatively to the other shales of the sections. In other words, the grain size itself of the clastic fraction of the sediment (clay vs. silt, which relates to pore-water and dissolved-oxidant circulation and replenishment) did not preside directly over OM accumulation. However, this must be replaced in the light of the works by Macquaker et al. (2010); Schieber and Southard (2009); Schieber and Yawar (2009) and Schieber et al. (2007) who studied the way organicmineral aggregates may accumulate in silt-rich deposits.

As far as redox conditions of deposition are concerned, the redox-proxying trace metals show that depositional conditions were not particularly prone to the development of oxygen limitation. The redox conditions may thus be termed as "normal marine" for many of the samples, according to the seminal sense of the term defined by Raiswell and Berner
(1985). "Normal marine" must be used to refer to oxygenated conditions within the water column and at the sediment-water interface, with suboxic to anoxic conditions developing at shallow depth below this interface. Here, the relative enrichments in $U$ and Mo observed for the proximal and intermediate sections (namely, Cap Gris-Nez and Cran du Noirda) indicate that the water column as well as the interface must have kept oxic, but for the samples yielding a detectable enrichment, reducing conditions must have got close to the sediment-water interface, inducing some diffusional capture of $\mathrm{U}$ and Mo (Algeo and Tribovillard, 2009; Scott and Lyons, 2012; Tribovillard et al., 2012). These redox conditions, inferred from trace metal concentrations, are corroborated by the presence of benthic foraminifers (A.Teresina, unpublished Master thesis). Benthic foraminifer assemblages are observed in various facies of the Argiles de Châtillon Fm., including the laminated shales. The assemblages are dominated by the genus Lenticulina (Kandel, 1969). However, it is known that some benthic foraminifers may be present in oxygen-poor environments.

The trace elements referred to as proxies to paleoproductivity, i.e., $\mathrm{Ni}$ and $\mathrm{Cu}$ (see discussion in Böning et al., 2015; Tribovillard et al., 2008), do not show any enrichment, thus suggesting that productivity was not high (we will not mention barium that cannot be used as a paleoproxy in the case of such relatively shallow environments). This conclusion is consistent with the one derived independently from organic parameters in the study by Tribovillard et al. (2001). The latter study concluded to productivity levels being of the same order of magnitude as that observed on today's marine platforms.

The predominance of silt over clay-sized minerals indicates that the depositional settings were not far away from shore, in turn suggesting that the sedimentation rate may have been relatively important, compared to common, claydominated, source rocks deposited in distal environments. In addition, the Argiles de Châtillon Fm. is (sometimes heavily) bioturbated (except for the laminated shales), which of course is not known to be a factor favorable to OM burial.

The distal-proximal gradient is observed within the Argiles de Châtillon Fm. and is best recorded by the lateral grain-size distribution. The organic content is only moderately impacted by the gradient. The land-derived, Type III, OM is expectedly a little more abundant at the Cap Gris-Nez as indicated by Rock Eval parameters (Fig. 5), but marine, Type II, OM is also present in the more proximal part of the basin. IH values appear not very different when comparing Cran du Noirda and Cap Gris Nez section, despite the proximal-distal gradient, whereas the Cap de la Crèche section shows relatively lower IH and higher Tmax values. Wignall and Newton (2001), basing on detailed facies observation, reported that oxygen levels were (at least episodically) lower in proximal settings of the Boulonnais than in more distal environments. An echo of this observation may be found in the redox-proxy distribution, since the Cran du Noirda and Cap Gris-Nez sections recorded slightly higher enrichment in Mo and U, compared to the Cap de la Crèche section (but not reaching anoxic conditions; Fig. 6). This can help explaining the somewhat lower HI/ higher Tmax values of the Cap de la Crèche section.

Thus, the first conclusion is that one may encounter potential source rocks even in settings that are not a priori prone to $\mathrm{OM}$ preservation and storage: relatively shallow 
environments dominated by deposition of silt-sized clastic particles, where sediment showing evidence of bioturbation and bio-irrigation were accumulated under normal-marine redox conditions. In addition, productivity was not high, but probably just comparable to what is observed on present platforms. The fact that the proximal-distal gradient did not impact significantly $\mathrm{OM}$ accumulation suggests that particle size distribution seems not to be a first-order parameter for OM accumulation, but, as evoked above, the fact that silt-rich deposits may trap organic-mineral aggregates must be kept in mind.

Despite environmental conditions that may be judged as unfavorable, or at least lowly favorable to OM preservation, the sediments studied here contain OM in noticeable abundance. The discrepancy must be explained.

\subsection{Iron limitation, enhancing OM sulfurization, then OM preservation}

Within the Cap de la Crèche section, one can observe a marked enrichment in organic S-rich OM (sulfurized amorphous $\mathrm{OM}$ ) in sediments deposited under normal marine conditions: the sediments accumulated up to several weight percents of vulcanized OM, whereas trace-metal distribution (together with the presence of benthic foraminifers and bioturbation) shows that bottom conditions were not reducing nor oxygen-deprived (except perhaps for the laminated intervals but they contain benthic forams, i.e., lenticulina), reminding the Cap de la Crèche section has the lowest enrichment-factors values for $\mathrm{U}$ and Mo (see Tribovillard et al., 2001 for detail about the abundance of AOM in this section). The other two sections studied shows lower TOC values. In addition, the strong S-rich OM accumulation of the Cap de la Crèche took place under conditions of moderate productivity. This observation is not common, since accumulation of abundant, sulfurized OM has been attributed hitherto for paleo-environments characterized by high productivity and/or low terrigenous supply (review in Vandenbroucke and Largeau, 2007). In a few words, OM sulfurization takes place when sulfide ions can react with functionalized organic molecules, which implies that all the sulfide ions are not monopolized by Fe(II). An iron deficiency, either relative or absolute, will favor sulfide-OM interactions. If reactive iron is little or not supplied to the depositional environment, the iron deficiency will be termed as absolute. If reactive iron is actually supplied, but if a high organic flux is also present (in case of high productivity), the large pool of sulfide ions generated through bacterial sulfate reduction (at the expense of OM) will exhaust the reactive iron pool. As a consequence, sulfide will be available for sulfurization (Tribovillard et al., 1994; Zaback et al., 1993).

In the case of the Argiles de Chattillon, according to the information gathered from previous studies about the Cap de la Crèche section (Tribovillard et al., 2015), the Fe/Al ratio is most of the time close to the "stoichiometric" value of the averaged upper crust (0.44; McLennan, 2001) or slightly above it (mean $\mathrm{Fe} / \mathrm{Al}=0.53 ; \mathrm{n}=63$ ). In the previous studies evoked above (Tribovillard et al., 2015), the part of the Fe content that is postulated to be in excess relative to the clastic fractionassociated part of the iron inventory (called $\mathrm{Fe}_{\mathrm{xs}}$ ) was calculated: taking into consideration the long diagenetic history of the sediments deposited about 152 millions years ago, as well as the detrital nature of the studied sedimentary rocks, it is considered that the chemically-inert fraction of the iron content was the part incorporated into the lattices of alumino-silicates; this non-reactive, or detrital part is calculated according to the following formula:

$\mathrm{Fe}_{\text {detrital }}=[\mathrm{Al}]_{\text {sample }} \mathrm{x}[\mathrm{Fe}] /[\mathrm{Al}]_{\text {upper crust }}$, with $[\mathrm{Fe}] /[\mathrm{Al}]_{\text {upper }}$ crust $=0.44$ (McLennan, 2001).

The iron content in excess to the detrital part then derived using the formula:

$\mathrm{Fe}_{\mathrm{xs}}=\mathrm{Fe}_{\text {total }}-\mathrm{Fe}_{\text {detrital }}$.

This fraction $\mathrm{Fe}_{\mathrm{xs}}$ is considered to give a good estimate of the "paleo" reactive-iron proportion, regardless of its present mineralogical carrier phase, after the successive steps of longterm diagenesis (see Scholz et al., 2014). In the case of the Cap de la Crèche section, $\mathrm{Fe}_{\mathrm{xs}}$ represents $16 \%$ on average of the total Fe inventory (Tribovillard et al., 2015). Thus, it is inferred that the amount of reactive iron was relatively limited in the sediments of this section, compared to the other sections studied here. It is concluded that sulfate-reducing reactions, induced by bacterially-mediated OM remineralization, operated with sediments rich in land-derived, clastic fractions, but limited in reactive iron (despite abundant silt and clay fractions). Consequently, in the Cap de la Crèche section, OM could react with free ("unemployed") sulfide ions and accumulate organic sulfur. This sulfurization protected OM against further bacterial remineralization and permitted its accumulation in relatively large proportions. The important point is that reactive-iron limitation triggered OM sulfurization in spite of a relatively low supply of OM: remineralizing a large pool of OM producing enough sulfide to immobilize all the reactive iron ions was not required, since the reactive iron pool was limited. Consequently, although the OM flux must have been moderate (moderate surface productivity), OM was protected through sulfur incorporation and thus stored in relatively large amounts.

Comparatively, excess iron is significantly more abundant in the other two sections that are more proximal than the Cap de la Crèche section. $\mathrm{Fe}_{\mathrm{xs}}$ represents $32 \%$ on average of the total Fe inventory in the Noirda section, and 30\% in the Cap de la Crèche section. For these two sections that are poorer in organic carbon than the Cap de la Crèche section, TOC values seem to be negatively correlated to the relative abundance of excess iron. The determination coefficient is of only 0.04 $(n=12)$ for the Gris Nez samples but is $0.61(n=14)$ for the Noirda samples. These results suggest that an increased amount of reactive iron may be associated to a decreased preservation of OM, but our data set does not allow us evidencing any clear-cut linear relation.

Iron, as an agent favoring OM remineralization was extensively discussed by Meyers et al. (2005) and Meyers (2007). For these authors, a relatively abundant flux of reactive iron will allow buffering dissolved sulfide via iron sulfidization (Canfield et al., 1992; Raiswell and Canfield, 1996). The toxic dissolved sulfide is thus put "harmless", which will stop preventing the presence of in-fauna. The possible presence of in-fauna will increase bioturbation and bio-irrigation, required to maintain oxidants such as dissolved oxygen and nitrate in pore waters, and hence enhance OM remineralization. Furthermore, active bioturbation and bio-irrigation can expand 
the thickness of the zone of aerobic OM degradation, thus increasing the exposure time of OM to dissolved oxygen. Reversely, these factors fostering OM degradation will be much tempered in case of reactive-iron limitation (Meyers, 2007). Our work adds one positive effect of iron limitation regarding $\mathrm{OM}$ accumulation: the sulfide ions, maintained at relatively high concentration in the dissolved state (if no ironinduced buffering takes place), as is the case for the Cap de la Crèche samples, will induce OM sulfurization, thus fostering $\mathrm{OM}$ preservation and hence, its burial. This OM accumulation is possible even in the case when $\mathrm{OM}$ is not particularly abundant, as is the case here.

Now an additional question is about the reason(s) why a relative iron deficiency may be observed in the case of the Cap de la Crèche, because the sediments are rich in fine-grained particles (silts and clays), which is a priori favorable to the presence of adsorbed iron ions (Burdige, 2006).

\subsection{The causes of the reactive-iron deficiency or presence}

The Argiles de Châtillon Fm. was deposited under relatively distal conditions accompanied by occasionallyreduced sedimentation rates, in a general context of sea-level rise (see Proust et al., 1995 or Wignall and Newton, 2001 for a detailed sequence stratigraphy description). Generally speaking, the reactive-iron supply to a basin may be conditioned by several factors:

- the relative width of the platform being flooded during sealevel rise. The larger the transgression, the larger the volume of reworked and remobilized sediments, which will impact the possible release of iron, coating fine particles;

- the flux of river-borne (Severmann et al., 2010) or airborne (e.g., Baddock et al., 2013; Buck et al., 2013) ironcoated particles;

- the flux of OM possibly associated with reactive iron (e.g., Barber et al., 2014; Bressac and Huieu, 2013; Krachler et al., 2012; Shigemitsu et al., 2013). Notably, Krachler et al. (2012) indicated that peatland-derived iron-bearing lignin particles may have a sufficiently long half-life in ocean water to sustain iron concentration in extended regions of the ocean;

- the offshore discharge of anoxic ground waters may generate $\mathrm{O}_{2}$-undersaturated bottom water masses that can be advected into nearshore waters (Peterson et al., 2016). These anoxic water masses may thus carry dissolved iron.

In parallel, iron may be redistributed with the marine environment itself. The current model (Anderson and Raiswell, 2004; Lyons and Severmann, 2006; Owen et al., 2012; Poulton and Canfield, 2005; Poulton and Raiswell, 2002; Raiswell and Canfield, 2012; Rickard, 2012; Scholz et al., 2013, 2014) explains how detrital iron deposited on the shelf may undergo suboxic diagenesis, thus releasing dissolved $\mathrm{Fe}$ (II). This aqueous iron may diffuse out of the sediment through the sediment-water interface where it is oxidized and trapped as reprecipitated $\mathrm{Fe}(\mathrm{III})$ oxyhydroxides. Nevertheless, a fraction of the dissolved iron thus released may be transported to the deeper (possibly euxinic) parts of the basin where it will be sequestered as iron sulfide (see discussion in Little et al., 2015).

Discussing these factors is rather hypothetical in the case of the Argiles de Châtillon, even if each of them can apply to the situation. That is why the attention will be instead focused on the composition of clay-mineral assemblages.

\subsubsection{Iron and clay-mineral assemblages}

The clay-mineral assemblages observed in the Boulonnais are composed of illite and kaolinite opposed in abundance to smectite, plus illite-smectite mixed-layer minerals and chlorite, the latter being negligible (Deconinck et al., 1982, 1996). Smectite is a potential carrier phase for reactive iron, whereas illite and kaolinite are less prone to be coated by reactive iron (Canfield et al., 1992; 1996; Chamley, 1989). Structural iron, relatively abundant in illite, cannot be considered to be reactive as long as it is part of the mineral lattice. Thus, attention must be paid to the relations between smectite abundance and iron proportions. Concerning the Cap de la Crèche section, the decarbonated fraction of the rocks of the entire section contain between 7 and $25 \%$ of clay-sized fraction $(<4 \mu \mathrm{m})$, and within the clay fraction itself, smectite amounts to less than $25 \%$ all along the section but the top three meters, inducing that smectite represents between 1 and $4 \%$ of the clastic fraction of the rock, which is negligible. Contrastingly, in the Cran du Noirda section with 5-17\% clay fraction, and with $0-93 \%$ of smectite in the clay assemblage, smectite represents between 0 and $11 \%$ of the clastic fraction of the rock composition. In the proximal Cap Gris-Nez section with $5-25 \%$ clay fraction, and with $0-93 \%$ of smectite in the clay assemblage, smectite represents between 0 and $7 \%$ of the clastic fraction of the rock composition. For the sample subsets for which data about both the clay-mineral assemblages and geochemical composition are available, one can observe a positive correlation between the proportion of smectite within the bulk decarbonated fraction of the rock and the relative reactive-iron abundance, as well as a negative relationship between bulk smectite and TOC in the case of the Noirda section (Fig. 7). In the case of the Cap Gris-Nez section, a clear negative correlation is drawn between bulk smectite content and TOC.

With this small sample set, we cannot be too ambitious in our interpretations, but we suggest that first, smectite could be associated with reactive iron (as may be observed in lacustrine or marine depositional environment; Mahamat Ahmat et al., 2016, 2017) and, second reactive iron could be associated with reduced OM preservation. The inference is twofold. First, if true, a correlation between reactive iron and smectite indicates that the amount of clay, even when present in relatively low proportions in the sediments of rocks, may have a significant impact on bulk-rock chemical composition. Second, and maybe more crucial, the correlation indicates that smectite may govern (at least partly) the amount of reactive iron of the sediment, which in turn impacts OM preservation (Mahamat Ahmat et al., 2016 and references therein). A higher abundance of reactive iron, capturing free sulfide and hence hampering OM sulfurization, may limit OM preservation. It is thus suggested that the amount of smectite may have a negative imprint on OM preservation and accumulation. 

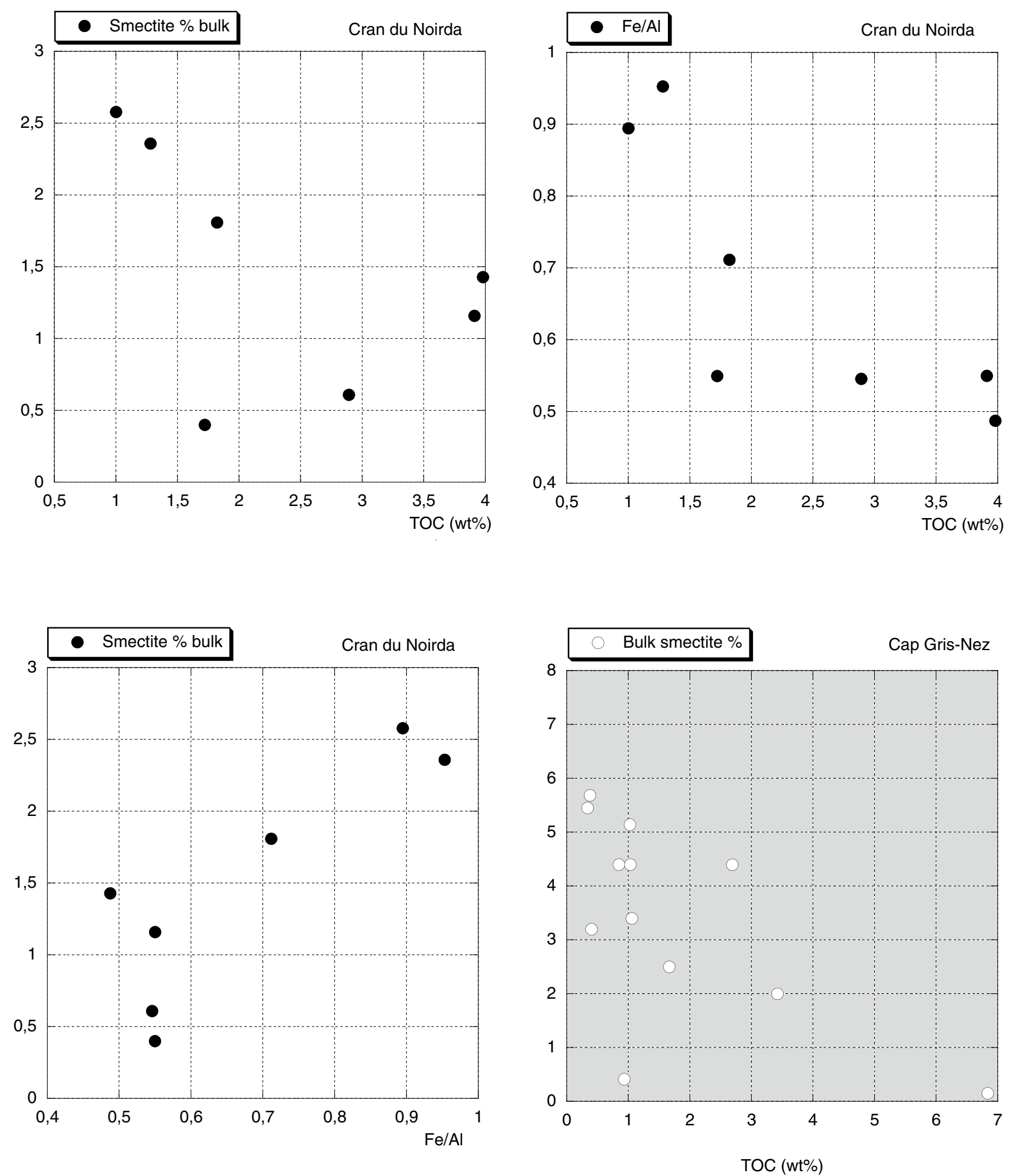

Fig. 7. Cross-plots illustrating the relationships between the Fe/ $\mathrm{Al}$ ratio, TOC values and the proportion of smectite within the carbonate-free fraction of the bulk rock.

This interpretation is in partial contradiction with usual interpretations. Clay minerals, especially smectite, are considered to have a positive effect regarding OM accumulation (Keil and Mayer, 2014; Mahamat Ahmat et al., 2016, 2017; Zhang et al., 2014 and references therein): OM is frequently associated with fine-grained clay minerals, due to their high specific surface area, cation exchange capacity and thence their strong adsorption capacity. In clay-rich sediments, $\mathrm{OM}$ abundance is commonly correlated with smectite abundance. This correlation suggests that the expandable internal surface of smectite (i.e., interlayer region) can sequester large amounts of molecular-scaled OM (Keil and 
Mayer, 2014; Kennedy and Wagner, 2011; however, see discussion in Mahamat Ahmat et al., 2016). Indeed, it has been suggested that enhanced organic matter preservation in sediments is largely due to increased smectite abundance in sedimentary record through geological time (Kennedy et al., 2006): organic matter, once associated with smectite-rich sediments, would be physically protected against microbial oxidation (see details in Keil and Mayer, 2014; Mahamat Ahmat et al., 2016, 2017; Zhang et al., 2014). However, as reminded above, smectite can also bring reactive iron, which will impact OM preservation: first, iron oxi-hydroxides are electron acceptors used by bacteria during OM remineralization; an input of reactive iron may thus fuel OM-consuming bacteria. Second, iron may impede sulfurization, as already mentioned. In other words, smectite is susceptible to convey both OM (organic molecules, i.e., dissolved organic carbon) and reactive iron, that is, the organic substrate and the iron used to consume the organic substrate.

All the studies showing a link between the abundance of smectite and the organic-molecule supply (see above) refer to present-day sediments or settling-particle fluxes; here we study ancient sediments. One hypothesis is that iron conveyed by smectite and progressively released during sediment (early) diagenesis, may have a deleterious effect on OM on the long run. Thus our preliminary results and interpretations bring new and complementary views about what is currently known regarding the role of smectite played in OM accumulation. However, our results are obviously too fragmentary and need further testing on other geological formations.

\section{Conclusions}

This work, synthesizing several previously published results and bringing new data about the detrital fraction of the rocks of the Argiles de Châtillon Fm., allows us having a consistent, multi-parameter, view of the depositional conditions that favored $\mathrm{OM}$ accumulation. Some of our conclusions are neither restricted to the Argiles de Châtillon Fm., nor to the Boulonnais region, but may be extended to many other clastic-dominated, relatively shallow, platform environments where black shales or even possible oil sourcerocks were accumulated. However, we do not consider the factors favoring OM accumulation discussed here, grounding on the central role of reactive iron, as being exclusive. Vulcanization is one processus among some (many?) other ones allowing for OM preservation. The first "take-home" message of the present work is that OM may be accumulated up to a few weight percents of organic carbon in rocks largely dominated by silt and with only $<20 \%$ clay-sized minerals, and showing evidence of bioturbation, and deposited under conditions of moderate productivity. In other words, a significant $\mathrm{OM}$ enrichment may be observed in ancient sediments deposited under environmental conditions that were not specifically prone to $\mathrm{OM}$ preservation. The second teaching is that our results suggest that the clay-mineral assemblages may have a significant impact on reactive iron abundance even when the clay fraction is present in modest proportions compared to silt. The third message is that smectite, usually considered to have a positive influence on $\mathrm{OM}$ adsorption and preservation, may also have a negative impact when this mineral can carry and release reactive iron during diagenesis. This iron may in turn react with sulfide ions released from OM decay mediated by sulfate-reducing bacteria, which prevents free sulfide to react with OM. OM sulfurization being limited by capture of free sulfide by reactive iron, $\mathrm{OM}$ preservation and accumulation will be hampered. However, this third message is suggested by our (quite simplistic) observations but still needs to be tested with other geological settings. Furthermore, even if our hypothesis is further confirmed, the exact mechanism is still to be determined: is reactive iron release by desorption from claymineral surface or by structural iron being reduced and solubilized through bacterial activity or clay-mineral diagenesis? Lastly, this study shows that a gradient in smectite distribution may be observed on a scale even as small as about $15 \mathrm{~km}$, resulting from the way sea-level variations (re-) mobilize the on-land clay-mineral inventories. The more-orless important abundance of smectite in an ancient sedimentary succession must be questioned in terms of sea-level variations, as well as in terms of evolution of on-land clay sources, even in small-dimension basins.

\section{Supplementary material}

Table S1 Grainsize parameters, carbonate content, composition of the clay-mineral assemblages and magnetic susceptibility of the analyzed samples from the Cap de la Crèche section.

Table S2 Grainsize parameters, carbonate content, composition of the clay-mineral assemblages and magnetic susceptibility of the analyzed samples from the Noirda section.

Table S3 Grainsize parameters, carbonate content, composition of the clay-mineral assemblages and magnetic susceptibility of the analyzed samples from the Cap Gris-Nez section.

The supplementary material is available at http://www.bsgf.fr/ 10.1051/bsgf/2017193/olm.

Acknowledgements. We thank the organizers of the thematic issue of the Bulletin de la Société Géologique de France, as well as the editorial office of the journal. We thank the technical staff of the LOG laboratory (Marion Delattre, Monique Gentric, Sylvie Regnier, Sandra Ventalon, Romain Abraham, Philippe Recourt). We thank Johann Schnyder and one anonymous referee for their helpful reviews. This work benefited from the support of the CNRS-INSU through the SYSTER program.

\section{References}

Ager D, Wallace P. 1966. The environmental history of the Boulonnais, France. Proc Geol Assoc 77: 385-417.

Ager D, Wallace P. 1970. The distribution and significance of trace fossils in the uppermost Jurassic rocks of the Boulonnais, Northern France. In: Crimes TP, Harper C, eds. Trace fossils. Geol $J$ spec issue 3: 1-17.

Al-Ramadan K, Morad S, Proust J-N, Al-Aasm I. 2005. Distribution of diagenetic alterations in siliciclastic shoreface deposits within a sequence stratigraphic Framework: evidence from the upper 
Jurassic Boulonnais, NW France. Journal of Sedimentary Research 75: 943-959.

Algeo TJ, Rowe H. 2012. Paleoceanographic applications of tracemetal concentration data. Chemical Geology 324-325: 6-18.

Algeo TJ, Tribovillard N. 2009. Environmental analysis of paleoceanographic systems based on molybdenum-uranium covariation. Chemical Geology 268: 211-225.

Anderson TF, Raiswell R. 2004. Sources and mechanisms for the enrichment of highly reactive iron in euxinic Black Sea sediments. American Journal of Science 304: 203-233.

Baddock M, Boskovic L, Strong C, McTainsh G, Bullard J, Agranovski I, et al. 2013. Iron-rich nanoparticles formed by aeolian abrasion of desert dune sand. Geochemistry, Geophysics, Geosystems 14: 3720-3729.

Barber A, Lalonde K, Mucci A, Gélinas Y. 2014. The role of iron in the diagenesis of organic carbon and nitrogen in sediments: a longterm incubation experiment. Marine Chemistry 162: 1-9.

Barnard T, Shipp DJ. 1981. Kimmeridgian foraminifera from the Boulonnais. Revue de Micropaléontologie 24: 3-26.

Behar F, Beaumont V, De B Penteado HL. 2001. Technologie RockEval 6 : performances et développements. Oil Gas Sci Technol Rev Inst Fr Pét Energies Nouv 56: 111-134.

Bialkowski A, Tribovillard N, Vergès E, Deconinck J-F. 2000. Étude haute résolution de la distribution et de la granulométrie des constituants organiques sédimentaires. Corrélations avec les variations du niveau marin. Kimméridgien/Tithonien du Boulonnais (Nord de la France). Comptes Rendus Académie des Sciences, Paris, II 331: 451-458.

Böning P, Shaw T, Pahnke K, Brumsack H-J. 2015. Nickel as indicator of fresh organic matter in upwelling sediments. Geochimica et Cosmochimica Acta 162: 99-108.

Boussafir M, Lallier-Vergès E. 1997. Accumulation of organic matter in the Kimmeridge Clay Formation: an update fossilisation model for marine petroleum source rocks. Marine and Petroleum Geology 14: 75-83.

Boussafir M, Lallier-Vergès E, Bertrand P, Badaut-Trauth D. 1994. Structure ultrafine de la matière organique dans des roches mères du Kimméridgien du Yorkshire (UK). Bulletin Société Géologique de France 165: 353-361.

Boussafir M, Gelin F, Lallier-Vergès E, Derenne S, Bertrand P, Largeau C. 1995a. Electron microscopy and pyrolysis of kerogens from the Kimmeridge Clay Fm., UK: source organisms, preservation processes and origin of microcycles. Geochimica et Cosmochimica Acta 59: 3731-3747.

Boussafir M, Lallier-Vergès E, Bertrand P, Badaut-Trauth D. 1995b. SEM and STEM studies on isolated organic matter and rock microfacies from a short-term organic cycle of the Kimmeridge Clay Formation (Yorkshire, UK). In: Lallier-Vergès E, Tribovillard N-P, Bertrand P, eds. Organic matter accumulation. Lecture Notes in Earth Sciences. Berlin: Springer, vol. 57, pp. 15-30.

Bout-Roumazeilles V, Cortijo E, Labeyrie L, Debrabant P. 1999. Clay-mineral evidence of nepheloid layer contribution to the Heinrich layers in the Northwest Atlantic. Palaeogeography, Palaeoclimatology, Palaeoecology 146: 211-228.

Braaksma H, Proust J-N., Kenter JAM, Drijkoningen GG, Filippidou N. 2006. Sedimentological, petrophysical, and seismic characterization of an upper Jurassic shoreface-dominated shelf margin (the Boulonnais, Northern France). Journal of Sedimentary Research 76: $175-199$.

Bressac M, Huieu C. 2013. Post-depositional processes: what really happens to new atmospheric iron in the ocean's surface? Global Biogeochemical Cycles 27: 1-12.
Brigaud B, Pucéat E, Pellenard P, Vincent B, Joachimski MM. 2008. Climatic fluctuations and seasonality during the Late Jurassic (Oxfordian-Early Kimmeridgian) inferred from d ${ }^{18} \mathrm{O}$ of Paris Basin oyster shells. Earth and Planetary Science Letters 273(1-2): 58-67.

Brumsack H-J. 2006. The trace metal content of recent organic carbon-rich sediments: implications for Cretaceous black shale formation. Palaeogeography, Palaeoclimatology, Palaeoecology 232: 344-361.

Buck CS, Landing WM, Resing JA. 2013. Pacific Ocean aerosols: deposition and solubility of iron, aluminum, and other trace elements. Marine Chemistry 157: 117-130.

Burdige DJ. 2006. Geochemistry of marine sediments. Princeton: Princeton University Press, 609 p.

Canfield DE, Raiswell R, Bottrell S. 1992. The reactivity of sedimentary iron minerals toward sulfide. American Journal of Science 292: 659-683.

Canfield DE, Lyons TW, Raiswell R. 1996. A model for iron deposition to euxinic Black Sea sediments. American Journal of Science 296: 818-834.

Carignan J, Hild P, Morel J, Yeghicheyan D. 2001. Routine analysis of trace elements in geochemical samples using flow injection and low-pressure on-line liquid chromatography coupled to ICP-MS: a study of geochemical references materials BR, DR-N, UB-N, ANG and GH. Geostandard Newsletter 25: 187-198.

Chamley H. 1989. Clay Sedimentology. Berlin: Springer, 623 p.

Chamley H, Deconinck J-F, Millot G. 1990. Sur l'abondance des minéraux smectitiques dans les sédiments marins communs déposés lors des périodes de haut niveau marin du Jurassique supérieur au Paléogene. CR Acad Sci Paris t. 311(II): 15291536.

Cox BM, Gallois RW. 1981. The stratigraphy of the Kimmeridge Clay of the Dorset type area and its correlation with some other Kimmeridgian sequences. Rep Instit geol Sci 80/4: 1-44.

Deconinck J-F, Chamley H. 1995. Diversity of smectite origins in late Cretaceous sediments: example of chalks from northern France. Clay Mineralogy 30: 365-379.

Deconinck J-F, Vanderaveroet P. 1996. Eocene to Pleistocene clay mineral sedimentation off New Jersey, Western North Atlantic (Sites 903 and 905). Proc. ODP, scientific results 150: 147-170.

Deconinck J-F, Chamley H, Debrabant P, Colbeaux J-P. 1982. Le Boulonnais au Jurassique supérieur : données de la minéralogie des argiles et de la géochimie. Annales de la Société Géologique du Nord, CII: 145-152.

Deconinck J-F, Geyssant JR, Proust J-N, Vidier JP. 1996. Sédimentologie et biostratigraphie des dépôts kimméridgiens et tithoniens du Boulonnais. Annales de la Société Géologique du Nord 4: 157-170.

Dera G, Brigaud B, Monna F, Laffont R, Pucéat E, Deconinck JF, et al. 2011. Climatic ups and downs in a disturbed Jurassic world. Geology 39(3): 215-218.

Derenne S, Largeau C, Casadevall E, Berkaloff C, Rousseau B. 1991. Chemical evidence of kerogen formation in source rocks and oil shales via selective preservation of thin resistant outer walls of microalgae: origin of ultralaminae. Geochimica et Cosmochimica Acta 55: 1041-1050.

Dunn CE. 1972. Trace element geochemistry of Kimmeridge sediments in Dorset, north west France and northern Spain. Ph.D. thesis, University of London.

El Albani A, Deconinck J-F, Herbin J-P, Proust J-N. 1993. Caractérisation géochimique de la matière organique et minéralogie des argiles du Kimméridgien du Boulonnais. Annales de la Société Géologique du Nord 2 ( $2^{\mathrm{e}}$ série): 113-120. 
El Albani A, Kuhnt W, Luderer F, Herbin JP, Caron M. 1999. Palaeoenvironmental evolution of the Late Cretaceous sequence in the Tarfaya Basin (southwest of Morocco). In: Cameron NR, Bate $\mathrm{RH}$, Clure VS, eds. The Oil and Gas Habitats of the South Atlantic, Geol Soc London Spec Publ 153: 223-240.

Espitalié J, Deroo G, Marquis F. 1986. La pyrolyse Rock Eval et ses applications. Part B Rev Inst Fr Pét 40: 755-784.

Folk RL, Ward WC. 1957. Brazos River bar: a study in the significance of grain-size parameters. Journal of Sedimentary Petrology 27: 3-26.

Fürsich FT, Oschmann, W. 1986. Storm shell beds of Nanogyra virgula in the Upper Jurassic of France. Neues Jarbuch Geologische Paläontologische Abhandlungen 172: 141-161.

Gelin F, Boussafir M, Derenne S, Largeau Cl, Bertrand Ph. 1995. Study of qualitative and quantitative variations in kerogen chemical structure along a microcycle: correlation with ultrastructural features. In: Lallier-Vergès E, Tribovillard N-P, Bertrand Ph, eds. Organic matter accumulation. Lecture Notes in Earth Sciences. Berlin: Springer, vol. 57, pp. 32-47.

Gelin F, Volkmann JK, Largeau C, Derenne S, Sinninghe Damsté JS, de Leeuw JW. 1999. Distribution of aliphatic, non-hydrolyzable biopolymers in marine microalgae. Org Geochem 30: 147-159.

Gertsch B, Adatte T, Tantawy AA, Berner Z, Mort HP, Fleitmann D. 2010. Middle and late Cenomanian oceanic anoxic events in shallow and deeper shelf environments of western Morocco. Sedimentology 57: 1430-1462.

Geyssant JR, Vidier J-P., Herbin J-P., Proust JN, Deconinck J-F. 1993. Biostratigraphie et paléoenvironnement des couches de passage Kimméridgien/Tithonien du Boulonnais (Pas de Calais) nouvelles données paléontologiques (ammonites), organisation séquentielle et contenu en matière organique. Géologie de la France 4: 11-24.

Hatem E, Tribovillard N, Averbuch O, Vidier D, Sansjofre P, Birgel D, et al. 2014. Oyster patch reefs as indicators of fossil hydrocarbon seeps induced by synsedimentary faults. Marine and Petroleum Geology 55: 176-185.

Hatem E, Tribovillard N, Averbuch O, Sansjofre P, Adatte T, Guillot F, et al. 2016. Early diagenetic formation of carbonates in a clasticdominated ramp environment impacted by synsedimentary faulting-induced fluid seepage - Evidence from the Late Jurassic Boulonnais Basin (N France). Marine and Petroleum Geology 72C: $12-29$.

Herbin JP, Geyssant JR. 1993. "Ceintures organique" au Kimméridgien/Tithonien en Angleterre (Yorkshire, Dorset) et en France (Boulonnais). CR Acad Sci Paris 317(II): 1309-1316.

Herbin JP, Müller C, Geyssant J, Mélières F, Penn IE. 1991. Hétérogénéité quantitative et qualitative de la matière organique dans les argiles du Val de Pickering (Yorkshire, UK): cadre sédimentologique et stratigraphique. Rev Inst Fr Pét 46: 675-712.

Herbin JP, Fernandez-Martinez JL, Geyssant JR, El Albani A, Deconinck J-F, Proust J-N. 1995. Sequence stratigraphy of source rocks applied to the study of the Kimmeridgian/Tithonian in the north-west European shelf (Dorset/UK, Yorkshire/UK and Boulonnais/France). Mar Petrol Geol 12: 177-194.

Hesselbo SP, Deconinck J-F., Huggett JM, Morgans-Bell HS. 2009. Late Jurassic palaeoclimatic change from clay mineralogy and gamma-ray spectrometry of the Kimmeridge Clay, Dorset, UK. Journal of the Geological Society, London 166: 1123-1133.

Kandel JC. 1969. Étude micropaléontologique et stratigraphique des falaises jurassiques du Boulonnais. Thèse $3^{\mathrm{e}}$ cycle, université de Paris, 159 p.

Keil RG, Mayer LM. 2014. Mineral matrices and organic matter. In Holland HD, Turekian KK, eds. Treatise on Geochemistry, Second Edition. Oxford: Elsevier, Vol. 12, pp. 337-359.
Kennedy MJ, Wagner T. 2011. Clay mineral continental amplifier for marine carbon sequestration in a greenhouse ocean. Proc Natl Acad Sci USA 108: 9776-9781.

Kennedy M, Droser M, Mayer ML, Pevear D, Mrofka D. 2006. Late Precambrian oxygenation; Inception of the clay mineral factory. Science 311: 1446-1449.

Krachler R, von der Kammer F, Jirsa F, Süphandag A, Krachler RF, Plessl C, et al. 2012. Nanoscale lignin particles as source of dissolved iron to the ocean. Global Biogeochemical Cycles 26: GB3024. DOI: 10.1029/2012GB004294.

Lafargue E, Marquis F, Pillot D. 1998. Les applications de Rock-Eval 6 dans l'exploration et la production des hydrocarbures, et dans les études de contamination des sols. Oil Gas Sci Technol Rev Inst Fr Pét Energies Nouv 53: 421-437.

Largeau C, Derenne S, Casadevall E, Berkaloff C, Corolleur M, Lugardon B, et al. 1990. Occurrence and origin of "ultralaminar" structures in "amorphous" kerogens of various source rocks and oil shales. Advance in Organic Geochemistry 89. Org Geochem 16: 889-895.

Little SH, Vance D, Lyons TW, McManus J. 2015. Controls on trace metal authigenic enrichment in reducing sediments: insights from modern oxygen-deficient settings. American Journal of Science 315: 77-119. DOI: 10.2475/02.2015.01].

Lyons TW, Severmann S. 2006. A critical look at iron paleoredox proxies based on new insights from modern euxinic marine basins. Geochimica et Cosmochimica Acta 70: 5698-5722.

Macquaker JHS, Keller MA, Davies SJ. 2010. Algal blooms and "marine snow": mechanisms that enhance preservation of organic carbon in ancient fine-grained sediments. Journal of Sedimentary Research 80: 934-942.

Mahamat Ahmat A, Boussafir M, Le Milbeau C, Guegan R, Valdès J, Guiñez $\mathrm{M}$, et al. 2016. Organic matter-clay interaction along a seawater column of the Eastern Pacific upwelling system (Antofagasta bay, Chile): Implications for source rock organic matter preservation. Marine Chemistry 179: 23-33.

Mahamat Ahmat A, Boussafir M, Le Milbeau C, Guegan R, De Oliveira T, Le Forestier L. 2017. Organic matter and clay interactions in a meromictic lake: implications for source rock organic matter preservation (Lake Pavin, France). Organic Geochemistry 109: 47-57.

Mansy J-L, Guennoc P, Robaszynski F, Amédro F, Auffret J-P, Vidier J.-P, et al. 2007. Notice explicative, carte géologique de la France (1/50 000), feuille Marquise, second ed. Orléans: BRGM, 213 p.

McLennan SM. 2001. Relationships between the trace element composition of sedimentary rocks and upper continental crust. Geochemistry, Geophysics, Geosystems 2: 2000GC000109.

Meyers SR. 2007. Production and preservation of organic matter: the significance of iron. Paleoceanography 22: PA4211. DOI: 10.1029/ 2006PA001332.

Meyers SR, Sageman BB, Lyons TW. 2005. Organic carbon burial rate and the molybdenum proxy: theroretical framework and the application to Cenomanian-Turonian oceanic anoxic event 2. Paleoceanography 20: PA2002. DOI: 10.1029/2004PA001068.

Minguely B, Averbuch O, Patin M, Rolin D, Hanot F, Bergerat F. 2010. Inversion tectonics at the northern margin of the Paris basin (Northern France): new evidence from seismic profiles and boreholes interpolation in the Artois area. Bulletin de la Société Géologique de France 181(5): 429-442.

Mongenot T, Boussafir M, Derenne S, Lallier-Vergès E, Largeau C, Tribovillard N. 1997. Sulphur-rich organic matter from Bituminous Laminites of Orbagnoux (France, upper Kimmeridgian) - the role of early vulcanization. Bulletin de la Société Géologique de France 168(3): 331-341. 
Owen JD, Lyons TW, Li X, Macleod KG, Gordon G, Kuypers MMM, et al. 2012. Iron isotope and trace metal records of iron cycling in the proto-North Atlantic during the CenomanianTuronian oceanic anoxic event (OAE-2). Paleoceanography 27: PA3223. DOI:10.1029/2012PA002328.

Peterson RN, Moore WS, Chappel SL, Viso RF, Libes SM, Peterson LE. 2016. A new perspective on coastal hypoxia: The role of saline groundwater. Marine Chemistry 179: 1-11.

Poulton SW, Canfield DE. 2005. Development of a sequential extraction procedure for iron: implications for iron partitioning in continentally derived particulates. Chemical Geology 214: 209-221.

Poulton SW, Raiswell R. 2002. The low-temperature geochemical cycle of iron: from continental fluxes to marine sediment deposition. American Journal of Science 302: 774-805.

Proust J-N. 1994. Notions élémentaires de stratigraphie séquentielle illustrées par un exemple. Ann Soc Géol du Nord 3(II): 5-25.

Proust J-N., Deconinck JF, Geyssant JR, Herbin J-P., Vidier J-P. 1993. Nouvelles données sédimentologiques dans le Kimméridgien et le Tithonien du Boulonnais (France). CR Acad Sci Paris 316(II): 363-369.

Proust J-N., Deconinck J-F., Geyssant JR, Herbin J-P., Vidier JP. 1995. Sequence analytical approach to the Upper KimmeridgianLower Tithonian storm-dominated ramp deposits of the Boulonnais (Northern France). A landward time-equivalent to offshore marine source rocks. Geologische Rundschau 84: 255-271.

Quijada M, Riboulleau A, Faure P, Michels R, Tribovillard N. 2016. Organic matter sulfurization on protracted diagenetic timescales: the possible role of anaerobic oxidation of methane. Marine Geology 381: 54-66.

Raiswell R, Berner RA. 1985. Pyrite formation in euxinic and semieuxinic sediments. Amer J Sci 285: 710-724.

Raiswell R, Canfield DE. 1996. Rates of reaction between silicate iron and dissolved sulfide in Peru Margin sediments. Geochimica et Cosmochimica Acta 60: 2777-2787.

Raiswell R, Canfield DE. 2012. The iron biogeochemical cycle past and present. Geochemical Perspective 1: 1-186.

Ramanampisoa L, Bertrand P, Disnar JR, Lallier-Vergès E, Pradier B, Tribovillard N. 1992. Étude à haute résolution d'un cycle du carbone organique des argiles du Kimméridgien du Yorkshire (G-B) : résultats préliminaires de géochimie et de pétrographie organique. CR Acad Sci Paris II 314: 1493-1498.

Rickard D. 2012. Sulfidic sediments and sedimentary rock. Developments in sedimentology. Amsterdam: Elsevier, vol. 65, $801 \mathrm{p}$.

Schieber J, Southard JB. 2009. Bedload transport of mud by floccule ripples: direct observation of ripple migration processes and their implications. Geology 37: 483-486.

Schieber J, Yawar Z. 2009. A new twist on mud deposition: mud ripples in experiment and rock record. The Sedimentary Record 7: 4-8.

Schieber J, Southard JB, Thaisen KG. 2007. Accretion of mudstone beds from migrating floccule ripples. Sciences 318: 1760-1763.

Schlirf M. 2003. Palaeoecologic significance of Late Jurassic trace fossils from the Boulonnais, N France. Acta Geologica Polonica 53: 123-142.

Schnyder J, Baudin F, Deconinck JF, Durlet C, Jan du Chêne R, Lathuilière B. 2000. Stratigraphie et analyse sédimentologique du passage Oxfordien/Kimméridgien dans le Boulonnais. Géologie de la France 4: 21-37.

Scholz F, McManus J, Sommer S. 2013. The manganese and iron shuttle in a modern euxinic basin and implications for molybdenum cycling at euxinic ocean margins. Chemical Geology 335: 56-68.
Scholz F, Severmann S, McManus J, Hensen C. 2014. Beyond the Black Sea paradigm: the sedimentary fingerprint of an open-marine iron shuttle. Geochimica et Cosmochimica Acta 127: 368-380.

Scott C, Lyons TW. 2012. Contrasting molybdenum cycling and isotopic properties in euxinic versus non-euxinic sediments and sedimentary: refining the paleoproxies. Chemical Geology 324-325: 19-27.

Severmann S, McManus J, Berelson WM, Hammond DE. 2010. The continental shelf benthic iron flux and its isotope composition. Geochimica et Cosmochimica Acta 74: 3984-4004.

Shigemitsu M, Nishioka J, Watanabe YW, Yamanaka Y, Nakatsuka T, Volkov YN. 2013. Fe/Al ratios of suspended particulate matter from intermediate water in the Okhotsk Sea: implications for longdistance lateral transport of particulate Fe. Marine Chemistry 157: 41-48.

Tegelaar EW, de Leeuw JW, Derenne S, Largeau C. 1989. A reappraisal of kerogen formation. Geochim Cosmochim Acta 53: 3103-3106.

Trentesaux A, Récourt P, Bout-Roumazeilles V, Tribovillard N. 2001. Carbonate grain-size distribution in hemipelagic sediments from a laser particle sizer. Journal of Sedimentary Research 71: 858-862.

Tribovillard N, Desprairies A, Lallier-Vergès L, Bertrand P. 1994. Sulfur incorporation of lipidic organic matter in reactive-iron deficient environments: a possible enhancement for the storage of hydrogen-rich organic matter. CR Acad Sci, Paris 319: 1199-1206.

Tribovillard N, Bialkowski A, Tyson RV, Vergès E, Deconinck J-F. 2001. Organic facies and sea level variation in the Late Kimmeridgian of the Boulonnais area (northernmost France). Marine and Petroleum Geology 18: 371-389.

Tribovillard N, Ramdani A, Trentesaux A. 2005. Controls on organic accumulation in Late Jurassic shales of Northwestern Europe as inferred from trace-metal geochemistry. In: Harris N, ed. The Deposition of Organic-Carbon-Rich Sediments: Models, Mechanisms, and Consequences. SEPM Special Publication 82: 145-164.

Tribovillard N, Algeo TJ, Lyons TW, Riboulleau A. 2006. Trace metals as paleoredox and paleoproductivity proxies: An update. Chemical Geology 232: 12-32.

Tribovillard N, Lyons TW, Riboulleau A, Bout-Roumazeilles V. 2008. A possible capture of molybdenum during early diagenesis of dysoxic sediments. Bulletin de la Sociéte Géologique de France 179(1): 3-12.

Tribovillard N, Algeo TJ, Baudin F, Riboulleau A. 2012. Analysis of marine environmental conditions based on molybdenum-uranium covariation - Applications to Mesozoic paleoceanography. Chemical Geology 324-325: 46-58.

Tribovillard N, Hatem E, Averbuch O, Barbecot F, BoutRoumazeilles V, Trentesaux A. 2015. Iron availability as a dominant control on the primary composition and diagenetic overprint of organic-matter-rich rocks. Chemical Geology 401: 67-82.

Tyson RV. 1995. Sedimentary organic matter: organic facies and palynofacies. London: Chapman \& Hall, 615 p.

Van der Weijden CH. 2002. Pitfalls of normalization of marine geochemical data using a common divisor. Marine Geology 184: 167-187.

Vandenbroucke M, Largeau C. 2007. Kerogen origin, evolution and structure. Organic Geochemistry 38: 719-833.

Waterhouse HK. 1999. Orbital forcing of palynofacies in the Jurassic of France and the United Kingdom. Geology 27: 511-514.

Wignall PB, Newton R. 2001. Black shales on the basin margin: a model based on examples from the Upper Jurassic of the Boulonnais, northern France. Sedimentary Geology 144: 335-356. 
Wignall PB, Sutcliffe OE, Clemson J, Young E. 1996. Unusual shoreface sedimentology in the upper Jurassic of the Boulonnais, Northern France. J Sedim Res 3: 577-586.

Williams CJ, Hesselbo SP, Jenkyns HC, Morgans-Bell HS. 2001. Quartz silt in mudrocks as a key to sequence stratigraphy (Kimmeridge Clay Formation (Late Jurassic, Wessex Basin, UK). Terra Nova 13: 449-455.
Zaback DA, Pratt LM, Hayes JM. 1993. Transport and reduction of sulphate and immobilisation of sulphide in marine black shales. Geology 21: 141-144.

Zhang J, Dong H, Zebg Q, Agrawal A. 2014. The role of Fe(III) bioreduction by methanogens in the preservation of organic matter in smectite. Chemical Geology 389: 16-28.

Cite this article as: Hatem E, Tribovillard N, Averbuch O, Bout-Roumazeilles V, Trentesaux A, Deconinck J-F, Baudin F, Adatte T. 2017. Small-scaled lateral variations of an organic-rich formation in a ramp-type depositional environment (the Late Jurassic of the Boulonnais, France): impact of the clastic supply, Bull. Soc. géol. Fr. 188: 31. 